only chapters 2 and 5 - and only the former in an extensive way - allow the reader to listen to these 'acoustic experiences' from a supporting website, a practice that has become normal. Despite this and other minor drawbacks, the volume makes a crucial contribution to sound studies and the anthropology of the senses in Southeast Asia. The reader will enjoy the deep and insightful ethnographic examples presented in each chapter, as well as the analysis of the relationship between sounds, hierarchies and power from the point of view of experience, language and music.

LORENZO CHIAROFONTE

SOAS University of London

\title{
The Southeast Asia connection: Trade and polities in the Eurasian world economy $500 B C-A D 500$ \\ By SING C. CHEw \\ Oxford: Berghahn, 2018. Pp. 178. Maps, Plates, Notes, Bibliography, Index. doi:10.1017/S0022463420000338
}

In this book, Sing C. Chew has selected his emphasis on Southeast Asia as a way to recalibrate the perceived imbalance in global history studies, wherein this region is sandwiched between two of the world's major civilisations, that of China and India, and often regarded as a peripheral zone. Chew shares his long-term investigation of Southeast Asia's role in the context of world history, specifically from $500 \mathrm{BC}$ through to $\mathrm{AD} 500$, a key period during the region's intensive engagement in global maritime trade networks. This book places Southeast Asian civilisations on an equal footing with other known civilisations to be examined in terms of their collective historical characteristics and global significance.

As Southeast Asia has no internal written records of its own during the time period of this study, the major sources for this book involve documentary evidence from neighbouring areas and archaeological reports from Southeast Asia and beyond, applied toward reconstructing the emergence of the region's social and economic complexity and maritime connections. Additional lines of evidence are mentioned when relevant in particular cases and aspects.

The Introduction reviews studies of macro-historical structures and worldsystems theory, and it proposes how a global historical narrative can refine and clarify the position of Southeast Asia in these terms. Following the Introduction, this book is divided into four numbered chapters, with themes of Southeast Asia's early context, connection with global trade networks, world economic systems, and political transformations.

Chapter 1 (Early Southeast Asia) summarises a rich amount of archaeological data and related historical literature, and it further investigates the region's economic and political trajectory. In this chapter, the discussion focuses on rice cultivation and metals fabrication, as they are the two major factors that stimulated cultural-social 
transitions in Southeast Asia's Neolithic Period and Bronze Age respectively. At the end of the Bronze Age (c.500 BC), cross-regional maritime networks had emerged and began to link Mainland Southeast Asia, numerous islands of Southeast Asia, China, and India.

Chapter 2 (Global Linkage: The First Eurasian World System) illustrates the landcrossing and ocean-crossing trade routes of the early Eurasian world, with a special focus on the maritime routes from west to east. These trading routes covered the geographical area from Europe and the Mediterranean to the Red Sea, from the Red Sea to East Africa and the Gulf, from the Gulf to the Indian Ocean, from the Indian Ocean to the South China Sea, and from the South China Sea to Korea and Japan. A detailed and intensive discussion of Southeast Asian maritime trading routes around $200 \mathrm{BC}$ to $\mathrm{AD} 500$ is presented clearly and informatively. Furthermore, the text touches on the uses of various types of ships and their construction traditions.

Chapter 3 (Southeast Asia in the Maritime Eurasian World Economy) describes the materials and goods that were traded among the trade networks discussed in chapter 2. This chapter first describes the physical items traded between Rome and India, and then it shifts attention to the items that originated from Southeast Asia and entered into the Eurasian world system. Southeast Asia's diverse trading partnerships included contacts in India and Roman areas to the west, as well as in China, Korea, Taiwan and Japan to the north and east. Among the many traded materials, spices, food crops, bronze, metals, timber, and precious stones are most representative. This chapter provides a laudable list of Southeast Asia's tradeable resources and enormous contribution to the Eurasian trading system.

Chapter 4 (Political Transformation in Southeast Asia) discusses Southeast Asia's polities and urbanisation development, along with the world trade system. Several examples are provided of the urbanisation process, such as in Vietnam, Thailand, Burma, and Cambodia in Mainland Southeast Asia. Among those examples, the case of the Oc Eo port city of Funan is described vividly as occupying a central position in the Eurasian maritime trading system, and its rise and fall clearly related to the shift of trading routes through time. Another section presents examples from Peninsular and Island Southeast Asia. This chapter delivers an intense discussion to correct the Indocentric mentality of interpreting Southeast Asia's socioeconomic and political transformation between $200 \mathrm{BC}$ and AD 500. This volume concludes with a short Methodological Reprise. In this part, Chew considers how the content of the prior chapters can support new views and paths forward in studies of the position of Southeast Asia in world economic systems history.

This book refers to a large volume of literature from different disciplines, primarily on ancient history but also archaeology, anthropology, linguistics, and environmental sciences. As a historian, Chew has incorporated the varied forms of information and interpretations provided by other scholars. Chew presents all this information through different time-ranges, from the oldest through to the newest, and from different geographical regions, from west to east. The information in each chapter is connected logically, interpreted carefully, and discussed thoughtfully. The scope of this book is admirable, given the wealth of information and the diversity of Southeast Asia's peoples, histories, cultures, and languages. This valuable book successfully demonstrates the 
great potential of studies on Southeast Asia, and Chew's efforts should be appreciated by scholars in the region and worldwide.

HSIAO-CHUN HUNG

The Australian National University

\section{Citizenship and democratization in Southeast Asia \\ Edited by ward berenschot, h.g.c. Schulte nordholt and laurens bakker Leiden: Brill, 2017. Pp. 320. Figures, Tables, Index. doi:10.1017/S002246342000034X}

Since the end of the Cold War and the rapid economic rise of East and Southeast Asia, scholars, governments and civil society pressure groups have debated whether the emergence of an educated urban middle class, inexorably educed political pressure to liberalise and democratise. In the 1950s, Barrington Moore coined the phrase 'no bourgeoisie, no democracy' and a significant literature associated with the leading scholars of comparative politics - Seymour Martin Lipset, Adam Przeworski, Philippe Schmitter, Guillermo O'Donnell, Lawrence Whitehead and Larry Diamond - have all tried, in various ways, to identify and empirically test the preconditions and processes determining the change from authoritarianism to electoral democracy 'as the only game in town'. In this literature Southeast Asia has always proved both anomalous and neglected.

Democracy has nowhere established deep roots in the region and its most successful postcolonial state, Singapore, remains an intractably single-party affair. The twenty-first century rise of an authoritarian China also saw a new political literature on democratic failure, populism, the sustainability of an enduring single party, and soft authoritarian rule.

This edited volume attempts to add substance to what Marina Otway termed semi-authoritarianism from the vantage point of post-Cold War and post-financial crisis developments in Indonesia, the Philippines, Malaysia, Cambodia and Thailand. In their introduction the editors assert that, 'although electoral democracy can be termed a success' in some states in Southeast Asia, it has so far failed 'to curtail the dominance of oligarchic elites and patronage politics'. Consequently, political development in post-colonial Southeast Asia remains a 'paradox' (p. 1).

Unravelling the paradox, this volume, the product of two European Union-funded workshops held between 2012 and 2013, explores politics 'from below'. To the extent the edited proceedings of the workshops possess an overarching theme, it is 'the importance of changing forms of citizenship in Southeast Asia' (p. 2). Citizenship in electoral but oligarchic postcolonial states, the editors maintain, is a neglected area of research that their volume endeavours to correct in order to understand the particularities of democratization politics in the region' (p. 2). Like most edited volumes of this ilk its findings are ultimately disappointing, the argument disjointed and its various chapters uneven and sometimes tangential, such as that of Mary Austin discussing the role of foreign domestic workers. 